\title{
SISTEM INFORMASI PELAYANAN JASA LAUNDRY BERBASIS WEB PADA TIRA LOUNDRY
}

\author{
Eka Permana*1, Depi Yuniar"2 \\ Program Studi Manajemen Informatika, STMIK Subang ${ }^{* 1}$ \\ Program Studi Manajemen Informatika, STMIK Subang ${ }^{\# 2}$ \\ E-mail: exadoank@yahoo.com ${ }^{* 1}$,depiyuniar96@yahoo.com ${ }^{\# 2}$
}

\begin{abstract}
Abstrak
Tira Laundry yang beralamat di jalan walahar/tegal kelapa subang adalah salah satu dimana usaha laundry ini menyediakan jasa cuci kiloan diantaranya jasa cuci dan kering, setrika, cuci baju, cuci celana, cuci bed cover, dan cuci selimut. Berdasarkan masalah yang ada, pada data pelayanan Tira Laundry masih menggunakan secara manual dari pencatatan data pelanggan sampai laporan, pendataan pakaian yang belum diambil oleh pelanggan pun masih menggunakan buku besar, dan pendaftaran konsumen masih dilakukan dengan ditulis tangan dalam sebuah buku aktifitas laundry, Sehingga untuk melakukan pencarian data pelanggan dan data laporan lainnya mengalami kesulitan dan membutuhkan proses yang lama. Dari permasaahan tersebut di buatlah sebuah sistem informasi pelayanan jasa laundry yang berisikan data-data pelanggan pada tyra laundry yang terjadi di setiap harinya.

Dalam melakukan penelitian ini menggunakan metodologi pengumpulan data pelanggan dan penyusunan melakukan wawancara mengenai semua kegiatan yang berhubungan dengan data pelanggan usaha jasa pada tyra laundry yang beralamat di jalan walahar/tegal kelapa subang. Hasil yang ingin dicapai adalah dapat membuat suatu sistem informasi pelayanan jasa laundry berbasis web pada tyra laundry, sehingga dapat meningkatkan efektivitas juga efesiensi kinerja usaha tyra laundry dan memudahkan pelayanan pada data laundry agar dapat berjalan dengan cepat dan mudah.
\end{abstract}

Kata kunci: Laundry, Sistem Informasi, Web.

Abstract

Tira Laundry which is located on the street Walahar / Tegal Kelapa Subang is one where the laundry business provides kilogram washing services including washing and dry services, irons, washing clothes, washing pants, washing bed covers, and washing blankets. Based on existing problems, the Tira Laundry service data still uses manually from recording customer data to reports, data collection clothing that has not been taken by customers is still using ledgers, and consumer registration is still done by handwritten in a laundry activity book, so as to searching for customer data and other report data is experiencing difficulties and requires a long process. From this problem, a laundry service information system is created which contains customer data on the laundry tyra that occurs on a daily basis.

In conducting this research using the methodology of collecting customer data and compiling conducting interviews about all activities related to customer service business data on tyra laundry having its address at Jalan Walahar / Tegal Kelapa Subang. The result to be achieved is to be able to create a webbased laundry service information system on tyra laundry, so as to increase the effectiveness of the efficiency of the tyra laundry business performance and facilitate the service of laundry data so that it can run quickly and easily.

Kata kunci: Laundry, Information System, Web.

\section{Pendahuluan}

Saat ini perkembagan teknologi, khususnya teknologi komputer telah mengalami kemajuan yang sangat pesat. Perkembangan teknologi tersebut tidak lepas dari peran manusia yang setiap saat terus memperbaiki dan mencari inovasi baru agar teknologi tersebut dapat digunakan untuk membantu pekerjaan manusia. Saat ini sudah banyak teknologi-teknologi yang dapat membantu dan mempermudah pekerjaan atau aktivitas manusia sehari-hari. Kita tahu bahwa teknologi komputer telah banyak digunakan diberbagai organisasi, baik organisasi besar maupun kecil. Teknologi komputer dimanfaatkan sebagai alat bantu untuk mempermudah pekerjaan dari perusahaan atau organisasi tersebut. Usaha Jasa Laundry semakin Lama semakin diminati oleh banyak orang sebagai lahan bisnis utama atau sampingan karena pendapatan yang dihasilkan cukup memadai, ditambah lagi dengan berbagai macam kesibukan dan pekerjaan yang cukup 
menyita waktu, sehingga tidak memiliki waktu untuk menyelesaikan pekerjaan Rumah Tangga, diantaranya seperti mencuci pakaian kotor.

Tira Laundry adalah salah satu usaha yang bergerak di bidang jasa cuci dan strika pakaian yang mulai berkembang. Dimana usaha jasa laundry ini menyediakan jasa cuci kiloan diantaranya jasa cuci dan kering serta setrika, cuci baju, cuci celana, cuci bed cover, dan cuci selimut. Berdasarkan masalah yang ada, pengolahan data pada Tira Laundry masih menggunakan secara manual dari pencatatan data pelanggan sampai laporan, pendataan pakaian yang belum diambil oleh pelanggan pun masih menggunakan buku besar, dan pendaftaran konsumen masih dilakukan dengan ditulis tangan dalam sebuah buku aktifitas laundry, semua ini menjadi permaslahan tersebut menjadi sulit, jadi dengan membangun sebuah sistem informasi dapat membantu kegiatan proses usahanya, sehingga dapat menyelesaikan permasalahanpermasalahan yang dihadapi pada usaha tira laundry. Dari permasaahan tersebut di buatlah sebuah sistem informasi pelayanan jasa laundry yang berisikan data-data pelanggan pada tyra laundry yang terjadi di setiap harinya.

Metode yang digunakan yaitu paradigma Waterfall (Classic Life Cycle), untuk lebih jelasnya tahapan dari paradigma Waterfall ini adalah :

a) System Engineering (Rekayasa Sistem), merupakan kegiatan untuk menentukan informasi apa yang dibutuhkan oleh sistem atau menentukan kebutuhan-kebutuhan dari sistem yang akan dibuat.

b) Analisys System (Analisis Sistem), dilakukan untuk memperoleh informasi tentang sistem, menganalisis data - data yang ada dalam sistem yang berhubungan dengan kegiatan. Informasi yang dikumpulkan terutama mengenai kelebihan dan kekurangan sistem.

c) Design (Perancangan), merupakan perancangan sistem baru berdasarkan data-data yang telah dikumpulkan pada tahap sebelumnya dengan cara merancang perangkat lunak diantaranya Diagram Konteks, Data Flow Diagram (DFD), Entity Relationship Diagram (ERD), Data Dictionary (Kamus Data), Struktur File, Struktur Menu, Merancang input dan rancangan Output.

d) Coding (Pengkodean), yaitu suatu kegiatan untuk membuat program atau mengimplementasikan hasil rancangan program aplikasi yang didalamnya memuat pengkonversian data kedalam sistem yang baru dan pengkonversian sistem secara berkala termasuk dalam hal pemeliharaan sistem itu sendiri.

e) Testing (Pengujian), yaitu kegiatan untuk melakukan pengetasan program yang sudah dibuat, apakah sudah benar atau belum, sudah sesuai atau belum diuji dengan cara manual jika testing sudah benar maka program boleh digunakan.

f) Maintenance (Perawatan), yaitu merupakan suatu kegiatan untuk memelihara program aplikasi yang telah dibuat, agar keutuhan program dapat terjaga seperti validasi data, updating data, dan menjaga program dari serangan virus, orang yang tidak berhak yang dapat merusak program.

\section{Pustaka}

Ada beberapa pendekatan dalam mendefinisikan sistem yaitu menekankan pada prosedur dan elemen atau komponennya.Menurut para ahli terdapat beberapa pendekatan dalam mendefinisikan sitem yaitu :

Secara sederhana, suatu sistem dapat diartikan sebagai suatu kumpulan atau himpunan dari unsur, komponen, atau variabel yang terorganisir, saling berinteraksi, saling bergantung satu sama lain, dan terpadu[1].

Sistem adalah kumpulan/grup dari subsistem/bagian/komponen apapun, baik fisikataupun nonfisik yang saling berhubungansatu sama lain dan bekerja sama secaraharmonis untuk mencapai satu tujuan tertentu[2].

Sistem adalah "suatu jaringan prosedur yang dibuat menurut pola yang terpadu untuk melaksanakan kegiatan pokok perusahaan[3]. Berdasarkan pengertian diatas dapat disimpulkan bahwa sistem adalah kumpulan dari komponen-komponen yang saling berkaitan satu dengan yang lain untuk mencapai tujuan dalam melaksanakan suatu kegiatan pokok perusahaan.

Web Server merunjuk pada perangkat keras (Server) dan perangkat lunak yang menyediakan layanan akses kepada pengguna melalui protocol komunikasi HTTP atau variannya (seperti FTP dan HTTPS) atau berkas-berkas yang terdapat pada suatu URL ke pemakai[4].

Basis data terdiri atas dua kata, yaitu basis dan data. Basis dapat di artikan sebagai markas atau gudang,tempat bersarang/berkumpul. Sedangkan data adalah representasi fakta dunia nyata yang mewakili suatu objek seperti manusia, (pegawai, siswa, pembeli, pelanggan), barang, hewan, peristiwa, konsep, keadaan, dan sebagainya, yang diwujudkan dalam bentuk angka, huruf, symbol, tes, gambar, bunyi, atau kombinasinya, sebagai satu kesatuan istilah[4].

ERD digunakan untuk pemodelan basis data menggunakan OODBMS maka perancangan basis data tidak perlu menggunakan ERD[5].

Simbol-simbol atau komponen-komponen yang digunakan dalam penggambaran Entity Relationship Diagram (ERD) [5] yaitu: 
a. Entitas (Entity) merupakan data inti yang akan disimpan, bakal table pada basis data, benda yang memiliki data yang harus disimpan datanya agar dapat diakses oleh aplikasi komputer, penamaan entitas biasanya lebih ke kata benda dan belum merupakan nama tabel.

b. Atribut Field atau kolom data yang butuh disimpan dalam suatu entitas.

c. Atribut Kunci Primer Field atau kolom data yang butuh disimpan dalam suatu entitas dan digunakan sebagai kunci akses record yang diinginkan, biasanya berupa id, kunci primer dapat lebih dari suatu kolom, asalkan kombinasi dari beberapa kolom tersebut dapat bersifat unik (berbeda tanpa ada yang sama).

d. Atribut Multinilai (Multivalue) Field atau kolom data yang butuh disimpan dalam suatu entitas yang dapat memiliki nilai lebih dari satu.

e. Relasi Relasi yang menghubungkan antar entitas, biasanya diawali dengan kata kerja.

f. Asosiasi (Association) Penghubung antara relasi dan entitas di mana di kedua ujungnya memiliki multiplicity kemungkinan jumlah pemakaian.

\section{Pembahasan}

Perancangan sistem merupakan tahapan untuk menggambarkan model yang akan dibuat. Tujuan dari perancangan sistem ini adalah untuk memberikan gambaran kepada para programer tentang sistem yang akan dikerjakan.perancangan ini merupakan persiapan untuk desain sistem secra terperinci.

a) Gambaran umum

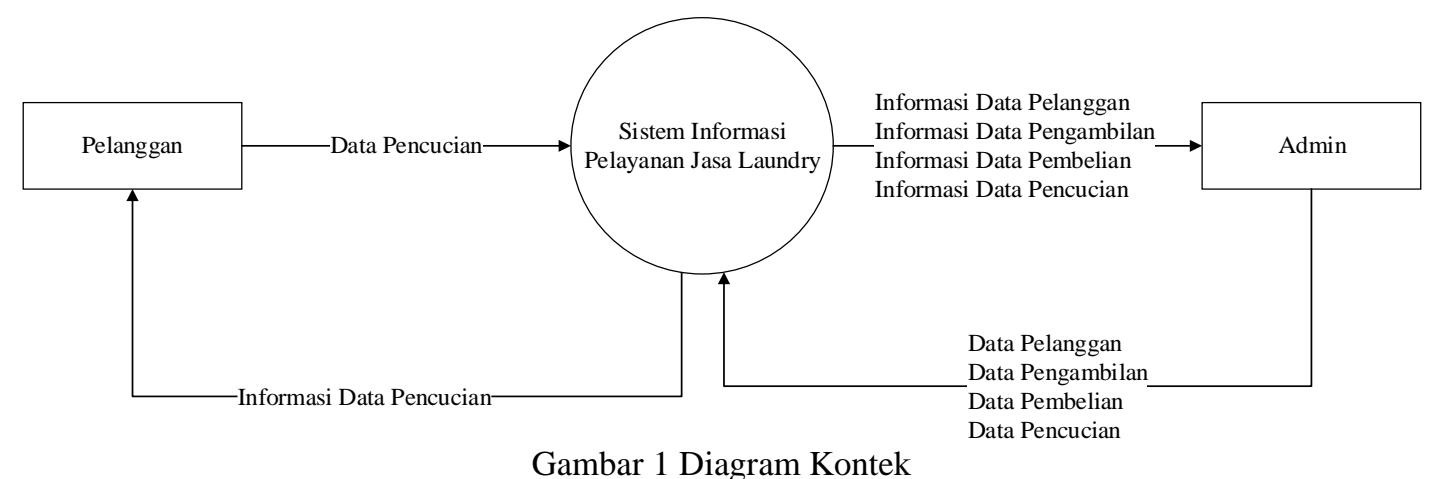

Diagram kontek sistem informasi Pelayanan Jasa Laundry Pada Tyra Laudry memiliki dua entiras yaitu Pelanggan dan Admin, Dari data pelanggan memberikan data pencucian ke sistem informasi, dari data sistem tersebut di olah oleh Admin berdasarkan Informasi Data Pelanggan, Informasi Data Pengambilan, Informasi Data Pembelian, dan Informasi Data Pencucian, admin juga dapat melakukan penginputan Data Pelanggan, Data Pengambilan, Data Pembelian, dan Data Pencucian Kepada Sistem dan Sistem menampilkan Informasi Data Pencucian kepada Pelanggan. 


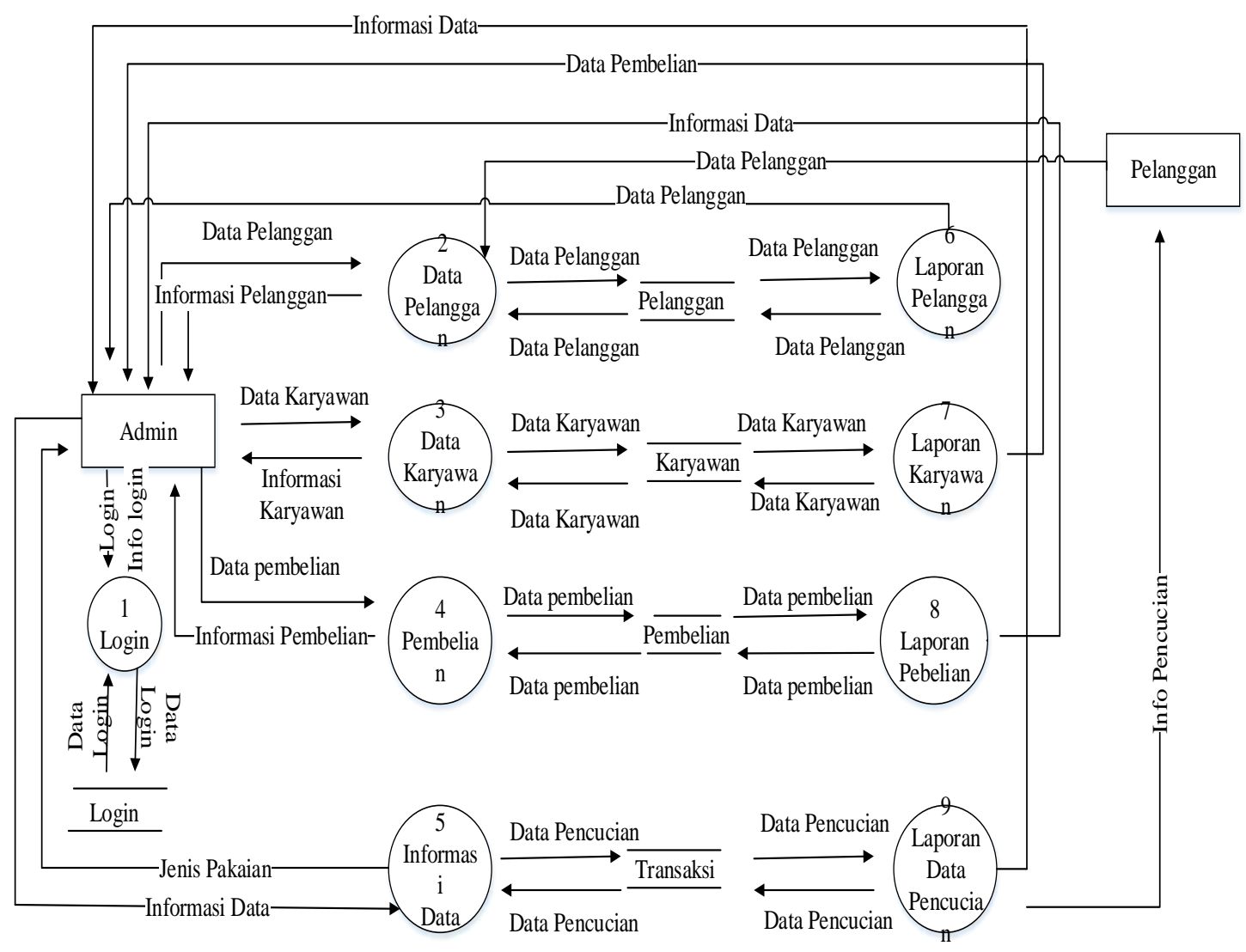

Gambar 2 DFD Level 1

Data Flow Diagram (DFD)atau diagram aliran dibuat setelah terbentuknya diagram konteks, dimana DFD ini menjelaskan proses input dan output data yang dibangun.Dari DFD level 1 terdapat 9 proses yaitu:

1. Admin melakukan login pada sistem dan sistem memberi informasi berhasil/gagal untuk login.

2. Admin melakukan penginputan data pelanggan ke sistem sesuai data yang di berikan pelanggan dan sistem menampilkan laporan data pelanggan.

3. Admin melakukan penginputan data karyawan ke sistem dan sistem menampilkan laporan data karyawan yang telah di input oleh admin.

4. Admin melakukan penginputan data pembelian barang ke sistem dan sistem menampilkan laporan data pembelian barang yang telah di input oleh admin.

5. Admin melakukan penginputan data pencucian pakaian sesuai data pelanggan yang mencuci ke sistem, dan sistem menampilkan laporan data pencucian pakaian yang telah di input oleh admin ke pelanggan.

1. Pada proses ini sistem menampilkan laporan data Pelanggan yang telah di input oleh admin yang diambil dari tabel pelanggan.

2. Pada proses ini sistem menampilkan laporan data Karyawan yang telah di input oleh admin yang diambil dari table Karyawan.

3. Pada proses ini sistem menampilkan laporan data Pembelian yang telah di input oleh admin yang diambil dari tabel Pembelian.

4. Proses ini sistem menampilkan laporan data pencucian sesuai barang yang dicuci dan di input oleh admin. 

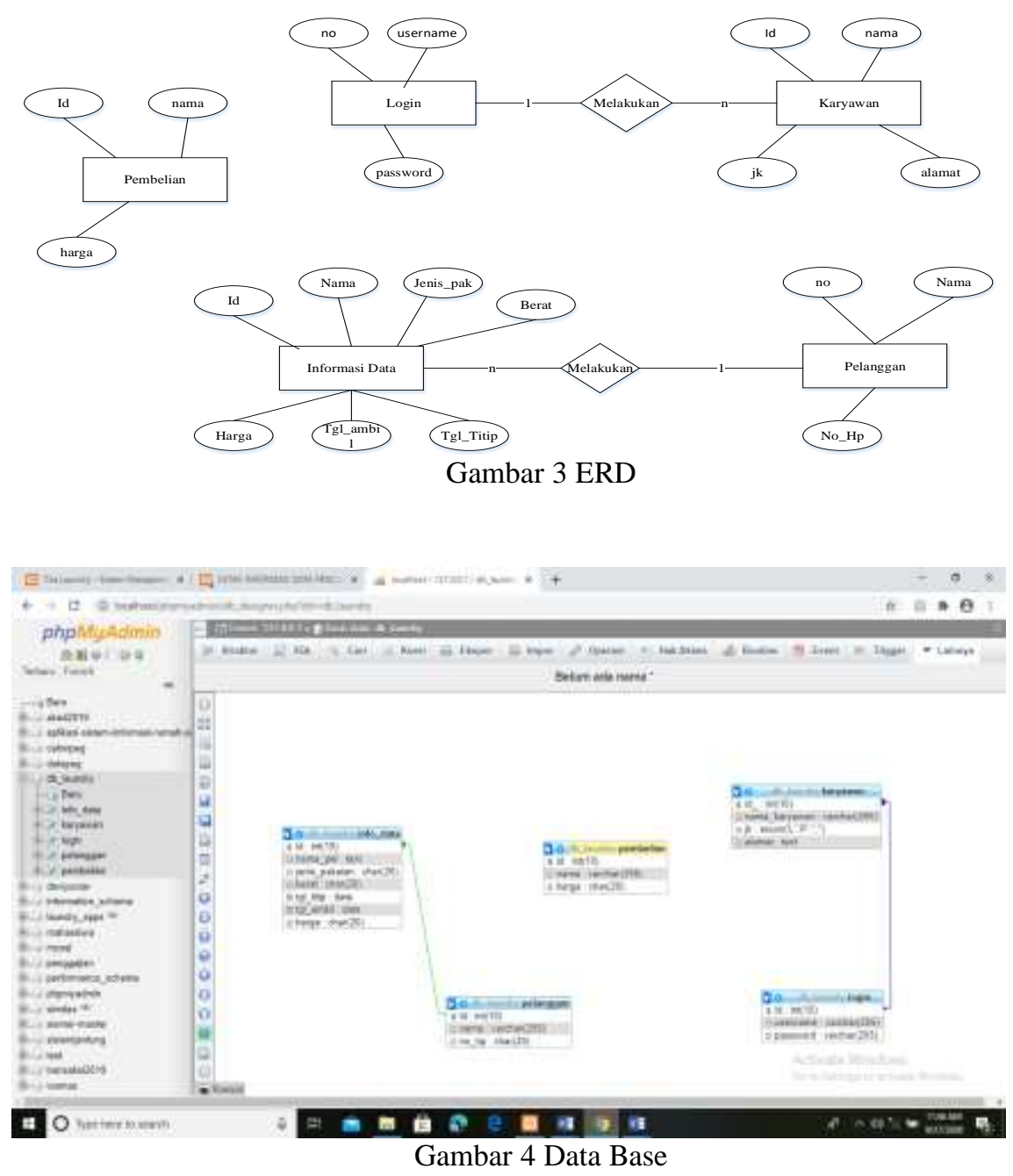

\section{Hasil}

Kegiatan ini bertujuan menerangkan secara singkat hasil dari perbuatan sistem informasi Pada Tira Laundry Berbasis Web. Tampilan menu Login adalah From yang akan masuk akses sistem yang digunakan oleh pengguna seperti pada gambar 5 Tampilan Login.

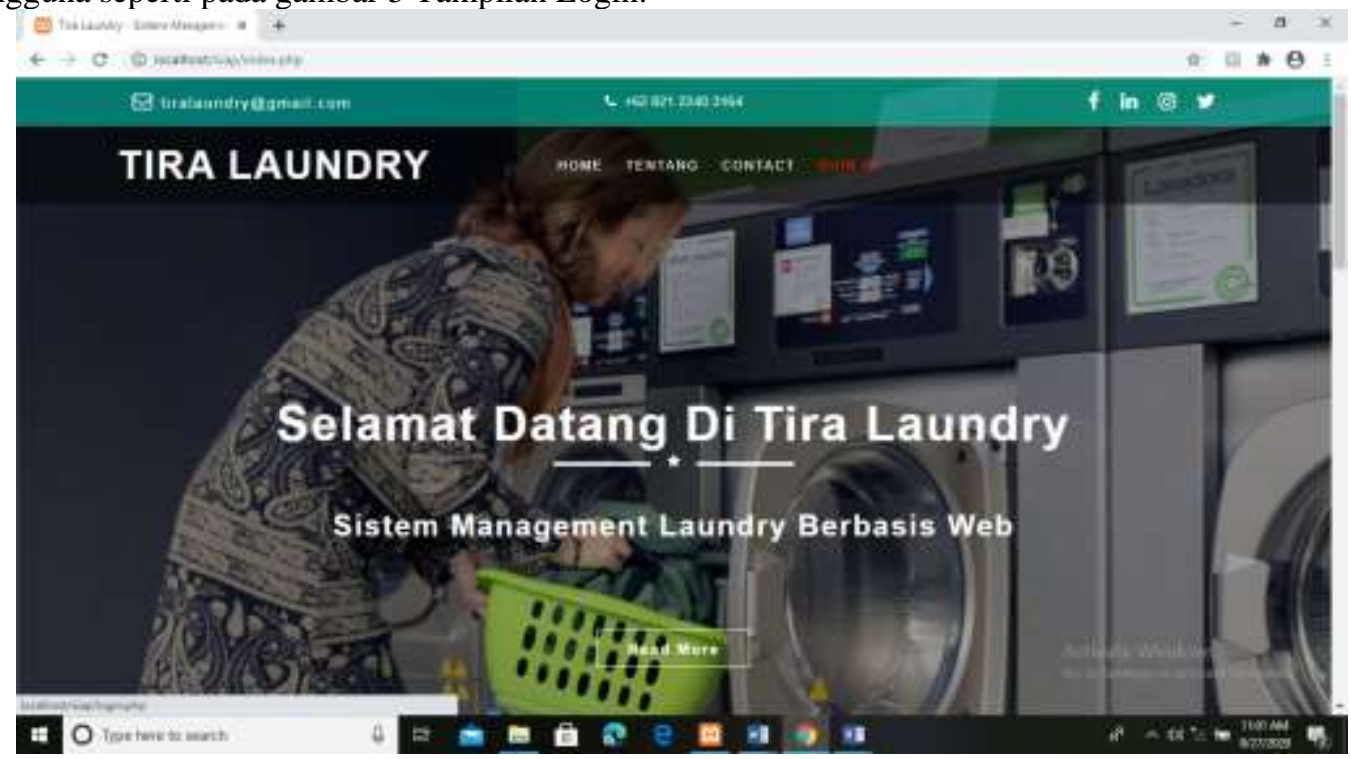

Gambar 5 Tampilan Login 
Tampilan dashboard adalah form yang berfungsi untuk menampilkan informasi pengguna yang telah melakukan login dan terdapat 5 button,yang pertama master yang di dalamnya ada batton Entry Karyawan, yang ke dua yang di dalamnya ada Entry Pelanggan, ketiga Entry Pembelian, keempat ada Laporan Informasi Data, dan yang ke lima terdapat button logut untuk pengguna keluar dari sistem tersebut. Seperti pada gambar 6 di bawah ini

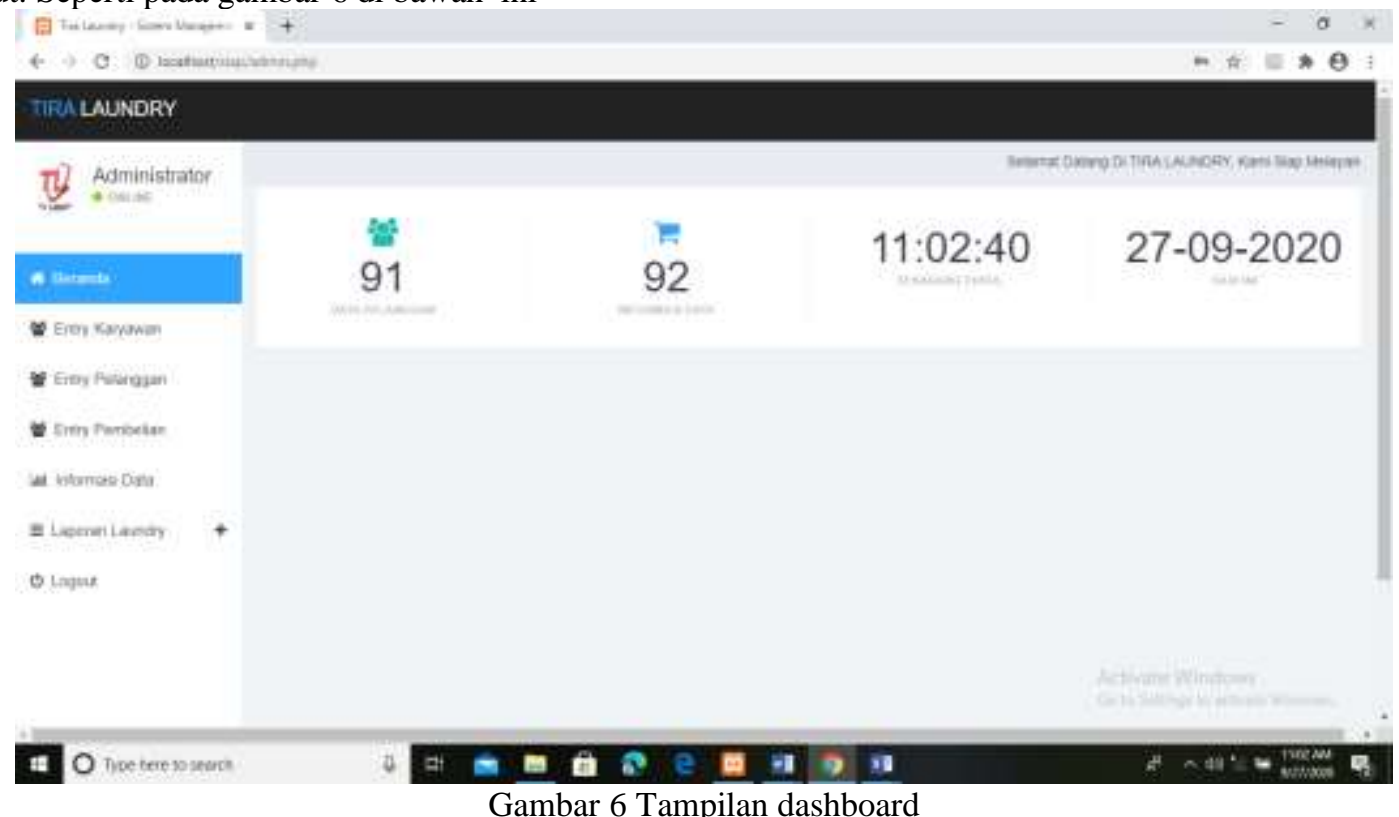

Gambar 6 Tampilan dashboard

Tampilan Data Karyawan, form yang berfungsi untuk menambah, dan Menyimpan Data Karyawan,yang telah di input sebelumnya oleh pengguna pada gambar 7 .

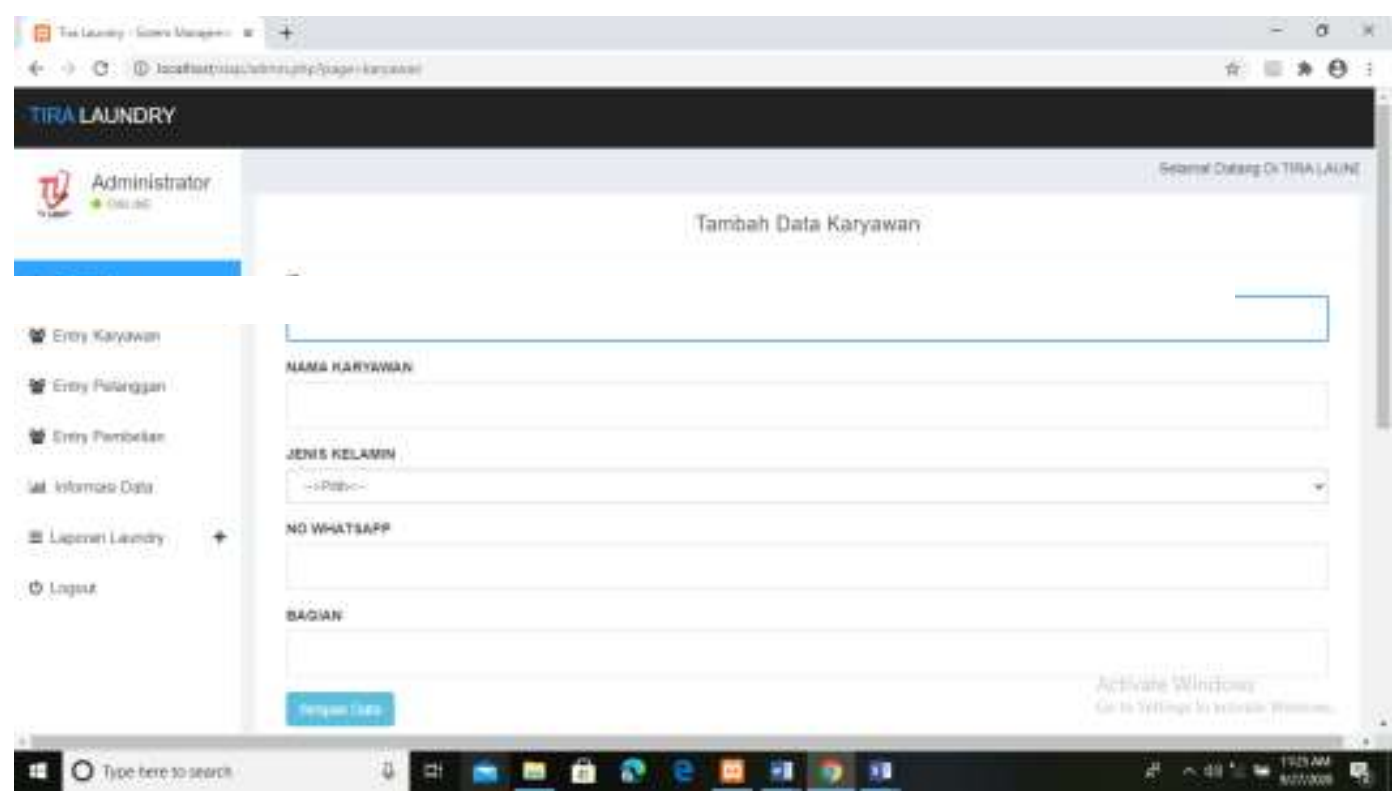

Gambar 7 Data Karyawan 
Tampilan Data Pelanggan yang berfungsi untuk menambah, dan Menyimpan Data Pelanggan, yang telah di input sebelumnya oleh pengguna ,seperti pada gambar 8 di bawah ini.

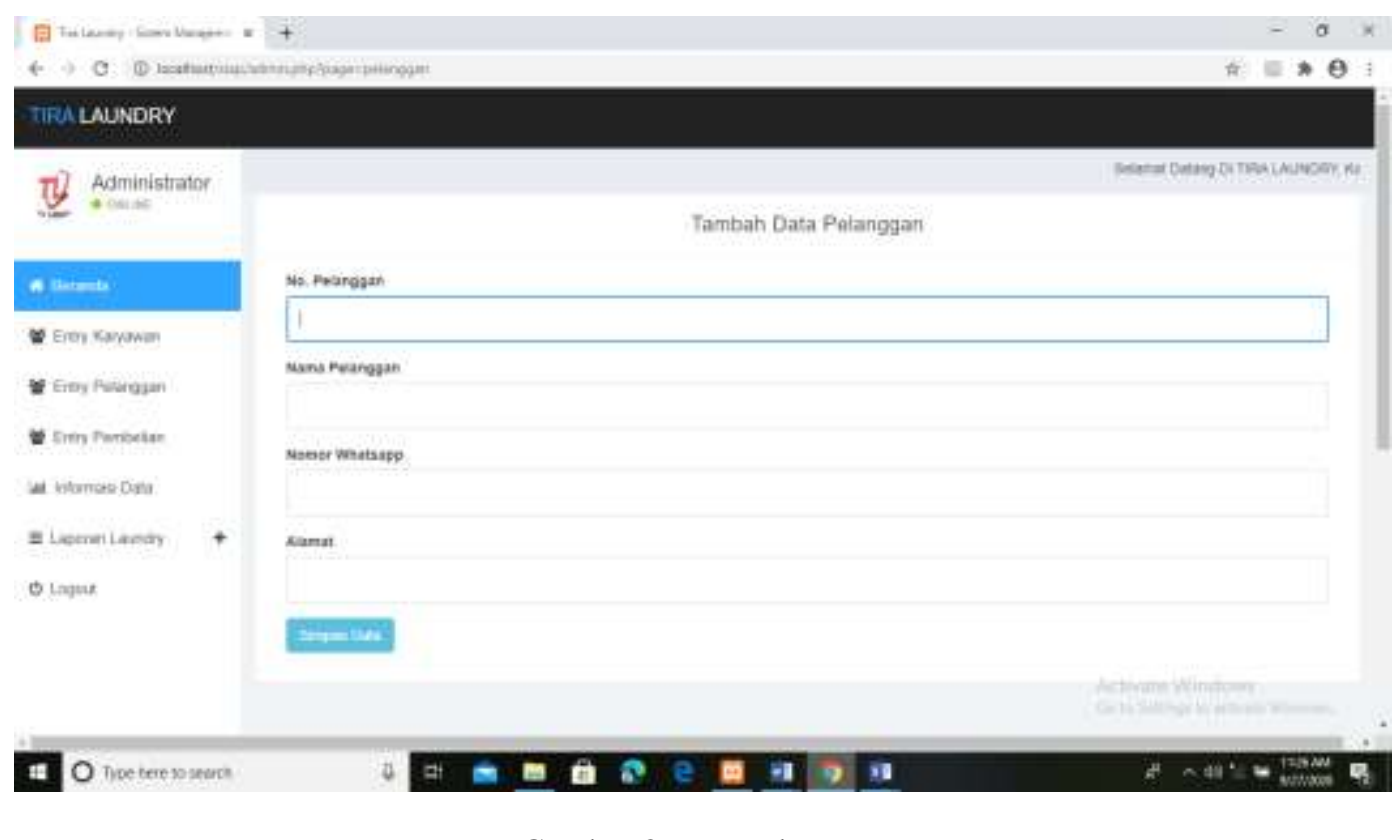

Gambar 8 Data Pelanggan

Tampilan Data Pembelian Barang yang berfungsi untuk menambah, dan Menyimpan Data Pembelian Barang, yang telah di input sebelumnya oleh pengguna, seperti pada gambar 9 di bawah ini.

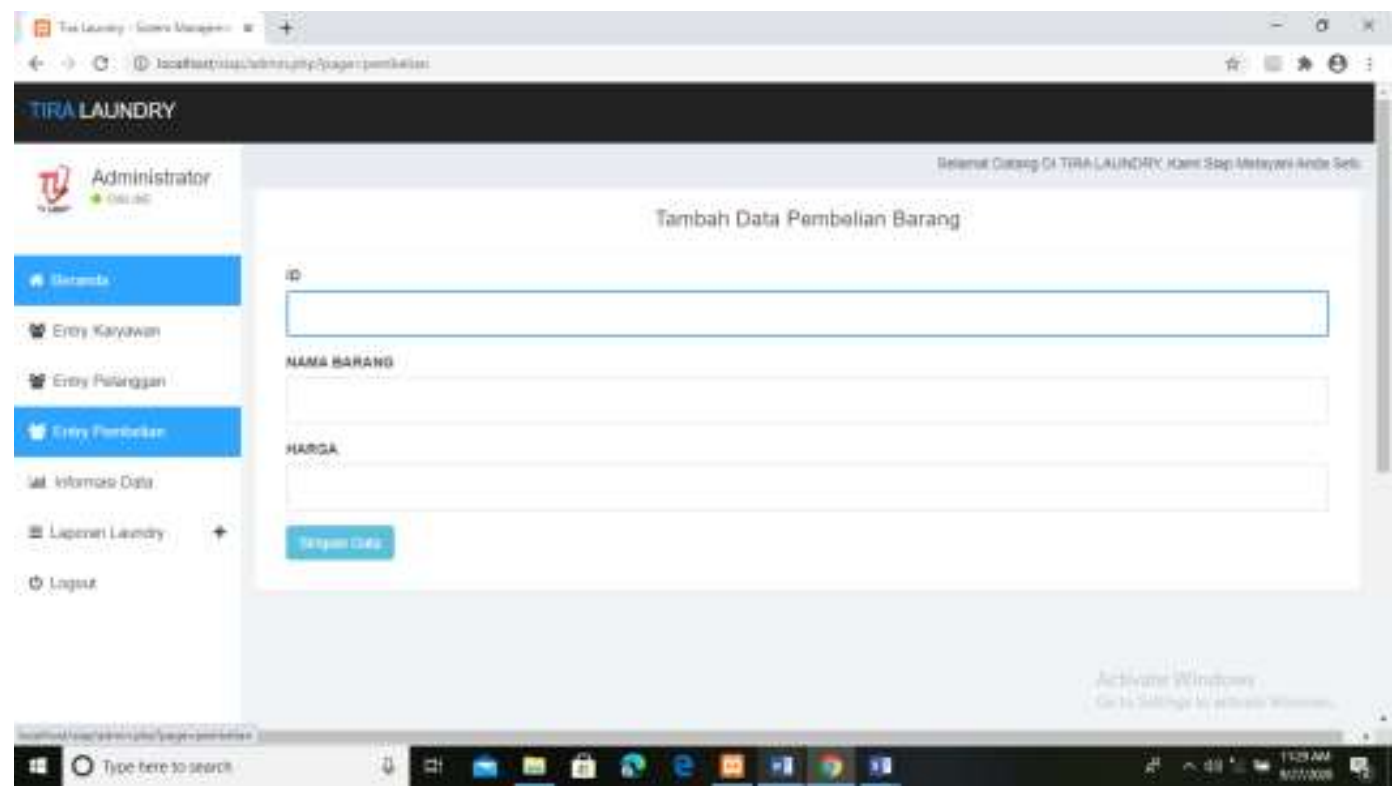

Gambar 9 Tampilan Data Pembelian Barang 
Informasi Data berfungsi sebagai Informasi Data Pelanggan yang di lakuan oleh pelanggan melalui pemilik yang telah di input oleh pengguna seperti pada gambar 10.

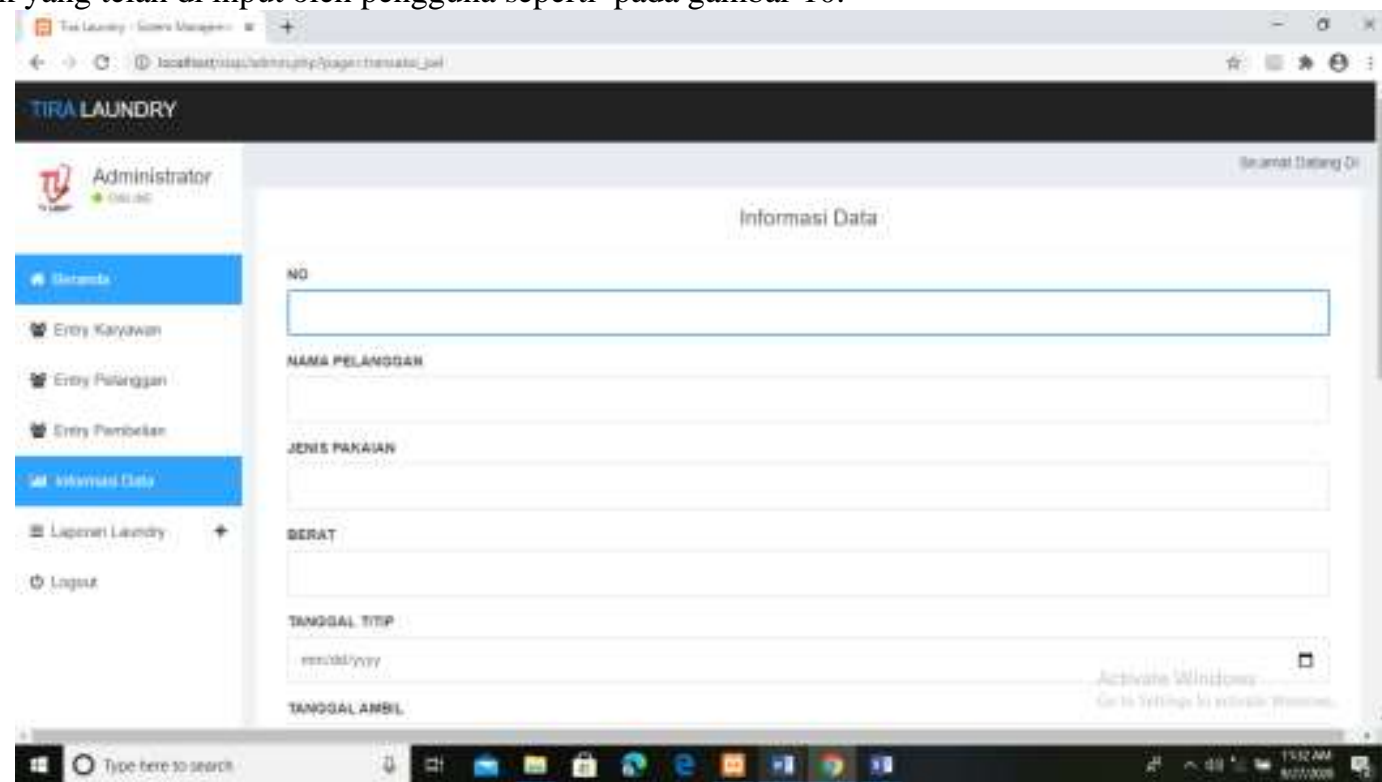

Gambar 10 Informasi Data

Tampilan laporan Data Pelanggan, laporan berfungsi untuk menyimpan dan mencari data Pelanggan yang telah di input oleh pengguna seperti pada gambar 11 di bawah ini.

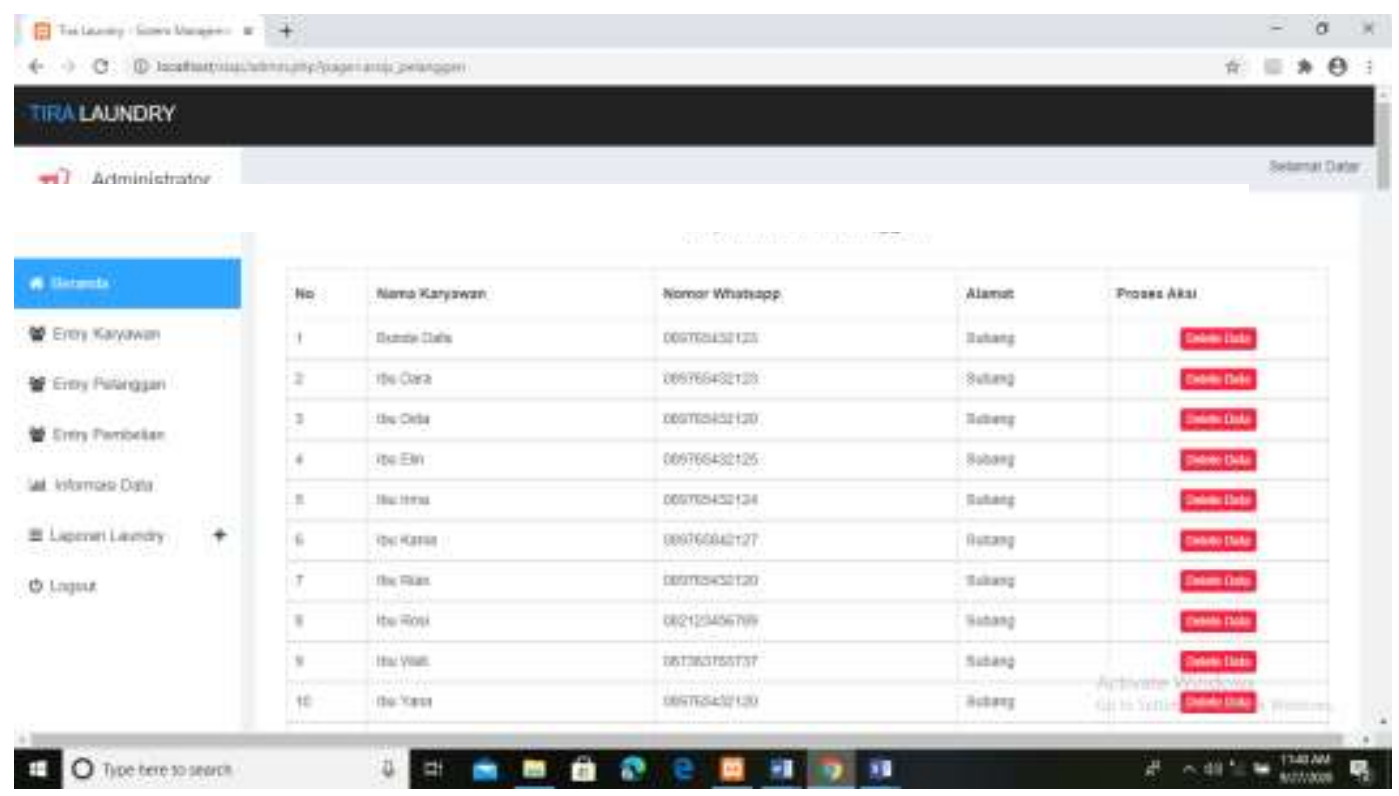

Gambar 11 Tampilan laporan Data Pelanggan 
Tampilan Informasi Data, laporan Informasi Data Semua Pelanggan berfungsi untuk menyimpan dan mencari data Pelanggan yang telah di input oleh pengguna seperti gambar 12 di bawah ini.

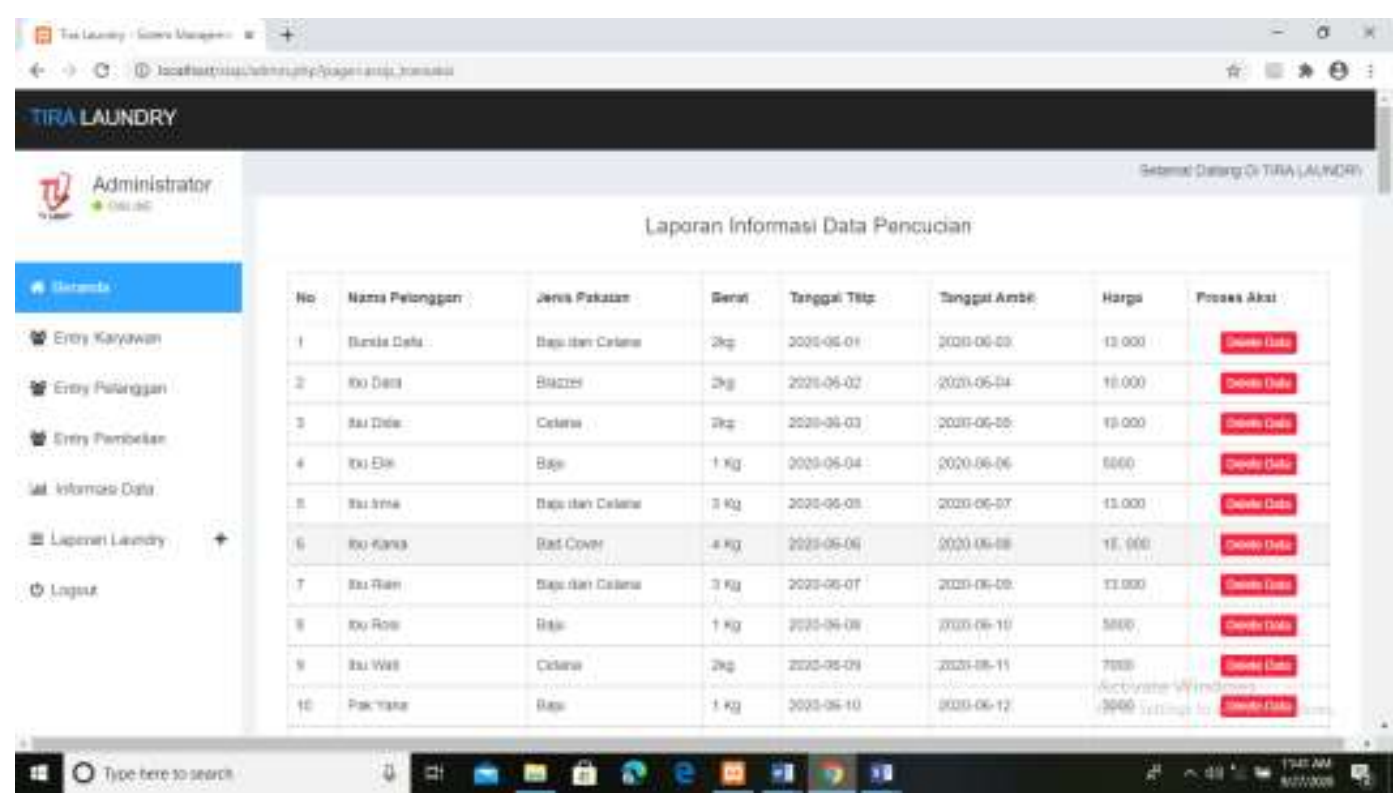

Gambar 12 Tampilan Informasi Data

Pengujian dilakukan untuk menguji kualitas dan juga kelemahan perangkat lunak yang telah dibuat,adapun hasil pengujian tersebut bisa di lihat pada tabel 1 Pengujian Sistem.

Tabel 1 Pengujian Sistem

\begin{tabular}{|c|c|c|c|c|}
\hline \multirow[t]{2}{*}{ No } & \multirow[t]{2}{*}{ Nama Form } & \multirow[t]{2}{*}{ Aksi } & \multicolumn{2}{|c|}{ Hasil Uji } \\
\hline & & & Berhasil & Gagal \\
\hline 1 & Login & Masukan username dan password & $\checkmark$ & \\
\hline 2 & Entry Data Karyawan & Klik entry data karyawan (pada gambar 4.1) & $\checkmark$ & \\
\hline 3 & Entry Data Pelanggan & Klik entry data pelanggan (pada gambar 4.2) & $\checkmark$ & \\
\hline 4 & Entry pembelian barang & Klik entry pembelian barang (pada gambar 4.3) & $\checkmark$ & \\
\hline 5 & Informasi Laporan Data & Klik entry Informasi data (pada gambar 4.4) & $\checkmark$ & \\
\hline 6 & $\begin{array}{l}\text { Laporan Loundry Data } \\
\text { Karyawan }\end{array}$ & $\begin{array}{l}\text { Klik Laporan laundry lalu klik data karyawan } \\
\text { (pada gambar 4.5) }\end{array}$ & $\checkmark$ & \\
\hline 7 & $\begin{array}{l}\text { Laporan Loundry Data } \\
\text { Pelanggan }\end{array}$ & $\begin{array}{l}\text { Klik Laporan laundry lalu klik data pelanggan } \\
\text { (pada gambar 4.6) }\end{array}$ & $\checkmark$ & \\
\hline 8 & $\begin{array}{l}\text { Laporan laundry data } \\
\text { pembelian barang }\end{array}$ & $\begin{array}{l}\text { Klik Laporan laundry lalu klik data pembelian } \\
\text { barang (pada gambar 4.7) }\end{array}$ & $\checkmark$ & \\
\hline 9 & $\begin{array}{l}\text { Laporan laundry } \\
\text { informasi data }\end{array}$ & $\begin{array}{l}\text { Klik Laporan laundry lalu klik informasi data } \\
\text { (pada gambar 4.8) }\end{array}$ & $\checkmark$ & \\
\hline 10 & Logout & $\begin{array}{l}\text { Klik tombol logout yang berada di bawah } \\
\text { informasi data }\end{array}$ & $\checkmark$ & \\
\hline
\end{tabular}




\section{Kesimpulan}

Hasil dari penelitian sebagai berikut :

1. Perancangan program sistem informasi berbasis web dengan pelayanan jasa laundry ini, dirancang untuk membantu proses kerja yang ada di tira laundry menjadi lebih efektif dan efisien. Terutama pada proses penerimaan data pelanggan, dan pembuatan laporan.

2. Membantu dalam meningkatkan kinerja pegawai dalam mengelola data laundry.

3. Sistem ini mempercepat proses pencarian data cucian konsumen, serta menghemat waktu konsumen untuk mengetahui status cucian.

4. Dengan adanya sistem ini proses pencarian data cucian konsumen lebih efektif dan efisien, serta menghemat waktu konsumen untuk mengetahui status cucian.

\section{Daftar Pustaka}

[1] Sutabri, T. (2012). analisis sistem informasi. yogyakarta: Andi.

[2] Djahir, \& Pratita. (2015). Sistem Informasi Manajemen . Yogyakarta: CV . Budi Utama.

[3] Mulyani, S. (2016). Sistem Informasi Manajemen Rumah Sakit : Analisis Dan Perancangan . Bandung: Abdi Sistematika.

[4] Fathansyah. (2012). Basis Data. Bandung: Informatika.

[5] Sukamto, \& Shalahuddin. (2015). Kelaborasi Rekayasa Perangkat Lunak Testrukur Dan Berorientasi Objek. Bandung: Informatika. 